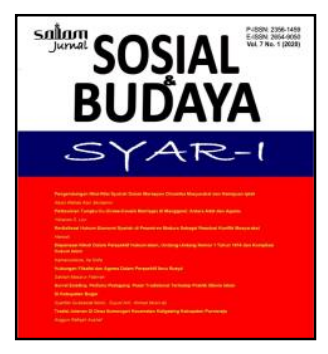

P-ISSN: 2356-1459. E-ISSN: 2654-9050

Vol. 8 No. 1 (2021), pp. 191-206

DOI: 10.15408/sjsbs.v8i1.19445

http://journal.uinjkt.ac.id/index.php/salam/index

\title{
Politik Hukum Pengalihan Izin Pertambangan pada Pemerintah Pusat Terhadap Kewenangan Pemerintah Daerah*
}

\author{
Rika Putri Wulandari ${ }^{1}$, Muhammad Helmi Fahrozi ${ }^{2}$ \\ d. \\ $10.15408 /$ sjsbs.v8i1.19445
}

Fakultas Hukum Universitas Pembangunan Nasional Veteran Jakarta

\begin{abstract}
Law Number 3 of 2020 is a new chapter in the development of mining law politics in Indonesia. The latest Minerba Law brings a number of major changes, one of which is the regulation of the authority to issue mining permits which has been transferred entirely to the central government. These changes caused controversy because the were considered contrary to constitutional values and the spirit of reform by eliminating the role of local governments in mineral and coal mining activities. The purpose of this study is to determine the legal politics of transferring mining permits to the central government and its implications for local government authority. This research is quantitative study using a normative juridical method through a statue approach and conceptual approach. This research finds that the legal politics of transferring mining permits to the central government is aimed at solving mining permit problems that facilitate investment activities so as to increase the country's economic growth. However, the implications of this transfer of authority make regional governments no longer have attributive authority to issue mining permits. The current mining law should move to create synergy between governments, not by placing the central government and local governments on different paths for the sustainability of future development. Keywords : Politics of law; Mining Permit; Local Government Authority.
\end{abstract}

\begin{abstract}
Abstrak
Undang-Undang Nomor 3 Tahun 2020 merupakan babak baru dalam perkembangan politik hukum pertambangan di Indonesia. UU Minerba terbaru membawa sejumlah perubahan besar salah satunya mengenai pengaturan kewenangan penerbitan izin pertambangan yang dialihkan seluruhnya kepada pemerintah pusat. Perubahan tersebut menimbulkan kontroversi karena dianggap bertentangan dengan nilai konstitusi dan semangat reformasi dengan menihilkan peran pemerintah daerah dalam kegiatan pertambangan minerba. Tujuan penelitian ini adalah untuk mengetahui politik hukum pengalihan izin pertambangan kepada pemerintah pusat dan implikasinya terhadap kewenangan pemerintah daerah. Penelitian ini merupakan penelitian kuantitatif dengan metode yuridis normatif melalui pendekatan undang-undang dan pendekatan konseptual. Penelitian ini menemukan bahwa politik hukum pengalihan izin pertambangan kepada pemerintah pusat ditujukan untuk mengurai permasalahan izin pertambangan yang memudahkan kegiatan investasi sehingga dapat meningkatkan pertumbuhan ekonomi negara. Namun, implikasi yang ditimbulkan akibat pengalihan kewenangan tersebut membuat pemerintah daerah tidak lagi memiliki kewenangan atributif dalam melakukan penerbitan izin pertambangan. Seharusnya hukum pertambangan yang ada saat ini bergerak untuk menciptakan sinergitas antar pemerintahan bukan dengan menempatkan pemerintah pusat dan pemerintah daerah pada jalan yang berbeda demi keberlangsungan pembangunan di masa depan.
\end{abstract}

Kata kunci : Politik Hukum, Izin Pertambangan; Kewenangan Pemerintah Daerah.

${ }^{*}$ Received: January 16, 2021, Revision: January 20, 2021, Published: February 08, 2021.

${ }^{1}$ Rika Putri Wulandari adalah Mahasiswa Fakultas Hukum Universitas Pembangunan Nasional Veteran Jakarta, Program Studi Sarjana Hukum.

${ }^{2}$ Muhammad Helmi Fahrozi adalah Dosen Fakultas Hukum Universitas Pembangunan Nasional Veteran Jakarta. 


\section{A. PENDAHULUAN}

Indonesia merupakan negara yang kaya akan sumber daya alam yang dimilikinya, salah satunya berada pada sektor pertambangan mineral dan batubara (minerba). Kekayaan sumber daya pada sektor ini tidak hanya berada pada satu wilayah saja, melainkan tersebar di berbagai daerah, baik bagian barat maupun timur, seperti timah dan tembaga di Sumatera, batubara dan minyak bumi di Kalimantan, granit dan bijih besi di Jawa, nikel di Sulawesi, dan emas serta tembaga di Papua. ${ }^{3}$ Sumber daya minerba menjadi salah satu sumber daya alam yang memiliki peran strategis bagi negara sehingga wewenang penguasannya berada di bawah kendali negara sesuai dengan amanat Pasal 33 ayat (3) UUD 1945 yang bertujuan untuk mencapai sebesar-besarnya kemakmuran rakyat. ${ }^{4}$

Kewenangan yang dimiliki oleh negara dalam rangka penyelenggaraan hak menguasai negara atas sumber daya alam ditransformasikan dalam beberapa bentuk menurut Putusan Mahkamah Konstitusi Nomor 002/PUU-I/2003, yakni mengadakan kebijakan (beleid) dan tindakan pengurusan (bestuursdaad), pengaturan (regelendaad), pengelolaan (beheersdaad), dan pengawasan (toezichthoudensdaad). ${ }^{5}$ Kewenangan penguasaan sumber daya minerba ini kemudian diselenggarakan oleh pemerintah. ${ }^{6}$ Penguasaan tersebut tidak hanya dilaksanakan oleh pemerintah pusat saja, melainkan juga dilaksanakan oleh pemerintah provinsi dan pemerintah kabupaten/kota sebagai bagian dari pemerintah daerah. Namun, keterlibatan pemerintah daerah dalam konteks penguasaan atas sumber daya minerba mengalami perubahan dari waktu ke waktu.

Sebelum hadirnya UU Nomor 23 Tahun 2014 tentang Pemerintahan Daerah, pemerintah provinsi dan pemerintah kabupaten/kota memiliki wewenang untuk melakukan kegiatan penguasaan atas sumber daya minerba. ${ }^{7} \mathrm{Hal}$ ini sejalan dengan ketentuan Pasal 4 ayat (2) UU Nomor 4 Tahun 2009 tentang Pertambangan Mineral dan Batubara yang menyebutkan bahwa penyelenggara kegiatan penguasaan atas sumber daya minerba adalah pemerintah pusat dan/atau pemerintah daerah. Kondisi tersebut menunjukkan adanya semangat desentralisasi dan otonomi daerah yang dicitakan oleh pembentuk undang-undang dalam konteks penguasaan atas sumber daya minerba. ${ }^{8}$ Kewenangan yang dimiliki oleh pemerintah daerah atas urusan pertambangan dikukuhkan kembali melalui Putusan Mahkamah Konstitusi Nomor 10/PUU-X/2012, dimana dalam putusan tersebut Mahkamah Konstitusi memberikan pertimbangan bahwa "pembagian

\footnotetext{
${ }^{3}$ Victor Imanuel Wiliamson Nalle, 2012, Hak Menguasai Negara Atas Mineral dan Batubara Pasca Berlakunya Undang-Undang Minerba, Jurnal Konstitusi, Vol.9, No. 3, hlm. 474.

${ }^{4}$ Dewan Perwakilan Rakyat Republik Indonesia, 2018, Naskah Akademik Rancangan Undang-Undang tentang Perubahan Atas Undang-Undang Nomor 4 Tahun 2009 tentang Pertambangan Mineral dan Batu Bara, DPR RI: Jakarta, hlm. 1.

${ }^{5}$ Nabilla Desyalika Putri dan Dian Agung Wicaksono, 2016, Implikasi Legislasi Pengambilalihan Kewenangan di Bidang Pertambangan Mineral dan Batubara Oleh Pemerintah Pusat (Legislation Implication Of The Takeover Authority In Mineraland Coal Mining By The Central Government), Jurnal Legislasi, Vol.3, No. 01, hlm. 20. Lihat juga Putusan Mahkamah Konstitusi Nomor 002/PUU-I/2003 perihal Pengujian Undang-Undang Nomor 22 Tahun 2001 tentang Minyak dan Gas Bumi terhadap UndangUndang Dasar Negara Republik Indonesia Tahun 1945, 15 Desember 2004, h. 208-209.

${ }^{6}$ Salim HS, 2012, Hukum Pertambangan Indonesia, Jakarta: Rajawali Pers:, hlm. 1.

${ }^{7}$ Diyan Isnaeni, 2018, Implikasi Yuridis Kewenangan Pemerintah Daerah Dalam Pemberian Ijin Usaha Pertambangan Menurut Undang-Undang Nomor 23 Tahun 2014, Jurnal Yurispruden, Vol. 1, No. 1, hlm. 37.

${ }^{8}$ Nabilla Desyalika Putri dan Dian Agung Wicaksono, Loc.Cit.
} 
urusan pemerintahan yang bersifat fakultatif haruslah berdasarkan pada semangat konstitusi yang memberikan otonomi seluas-luasnya kepada pemerintah daerah. ${ }^{\prime \prime}$

Namun perkembangan penguasaan sumber daya minerba justru cenderung mengabaikan amanat yang diberikan oleh Mahkamah Konstitusi. Sejak lahirnya UU Nomor 23 Tahun 2014 tentang Pemerintahan Daerah, pemerintah kabupaten/kota tidak lagi memiliki wewenang dalam penyelenggaraan urusan kehutanan, kelautan, serta energi dan sumber daya mineral, termasuk dalam hal penerbitan izin pertambangan. Kewenangan tersebut beralih kepada pemerintah pusat dan pemerintah provinsi melalui ketentuan Pasal 14 ayat (1) UU Nomor 23 Tahun 2014. ${ }^{10}$ Ketentuan lebih lanjut mengenai kewenangan yang dimiliki oleh pemerintah pusat dan pemerintah provinsi dalam penyelenggaraan urusan minerba kemudian tertuang dalam Lampiran UU Pemda a quo.

Polemik lain mengenai izin pertambangan kembali muncul sejak disahkannya UU Nomor 3 Tahun 2020 yang merevisi UU Nomor 4 Tahun 2009 tentang Pertambangan Mineral dan Batubara. Sebelum revisi UU Minerba tersebut disahkan, pada saat yang bersamaan, pemerintah dan DPR juga tengah melakukan pembahasan mengenai draft UU Cipta Kerja yang termasuk ke dalam Prolegnas Prioritas tahun 2020. Sebagaimana yang diketahui bahwa UU Cipta Kerja dikonstruksikan sebagai sebuah payung hukum yang akan mengurai permasalahan dalam kemudahan berinvestasi salah satunya adalah berkenaan dengan permasalahan izin, termasuk didalamnya adalah kegiatan izin di sektor pertambangan minerba. Permasalahan kemudian muncul ketika hampir secara keseluruhan substansi yang termuat dalam UU Cipta Kerja merupakan substansi UU Minerba yang tengah dibahas oleh DPR bersama Presiden. Pembahasan kedua UU tersebut yang cenderung memiliki kesamaan substansi menimbulkan kekhawatiran di tengah masyarakat akan terjadinya tumpang tindih pengaturan yang akan berdampak pada kegiatan usaha pertambangan dan tidak terpenuhinya jaminan kepastian hukum. ${ }^{11}$

Namun pada akhirnya, UU Cipta Kerja yang disahkan Oktober lalu tidak mengatur mengenai ketentuan yang sudah termaktub dalam revisi UU Minerba sebagai bentuk harmonisasi antar peraturan perundang-undangan. Ketentuan mengenai peralihan kewenangan penerbitan izin usaha pertambangan kepada pemerintah pusat tetap berada pada UU Nomor 3 Tahun 2020 sebagaimana yang termaktub dalam substansi Pasal 35 ayat (1). Hal ini merupakan implikasi dari eksistensi Pasal 4 ayat (2) UU Nomor 3 Tahun 2020 menyebutkan bahwa penguasaan negara atas sumber daya mineral dan batubara sepenuhnya dilakukan oleh pemerintah pusat. Keberadaan dari Pasal 4 ayat (2) UU Nomor 3 Tahun 2020 tersebut kemudian menghapuskan kewenangan pemerintah daerah yang

9 Putusan Mahkamah Konstitusi Nomor 10/PUU-X/2012 perihal Pengujian Undang-Undang Nomor 4 Tahun 2009 tentang Pertambangan Mineral dan Batubara terhadap Undang-Undang Dasar Negara Republik Indonesia Tahun 1945, 20 November 2012, hlm. 94.

${ }^{10}$ Rizkyana Zaffrinda Putri, Lita Tyesta A.L.W, 2015, Kajian Politik Hukum Tentang Perubahan Kewenangan Pemberian Izin Usaha Pertambangan Mineral dan Batubara, Jurnal Law Reform, Vol. 11 No. 2, hlm. 201.

11 Yanita Petriella, Adu Cepat antara RUU Cipta Kerja dan RUU Minerba, Ini Kata Ahli Tambang, https://ekonomi.bisnis.com/read/20200225/44/1205770/adu-cepat-antara-ruu-cipta-kerja-dan-ruu-minerbaini-kata-ahli-tambang diakses pada 13 Desember 2020. 
sebelumnya diatur dalam Pasal 7 dan Pasal 8 UU Nomor 4 Tahun 2009. ${ }^{12}$ Kondisi ini menunjukkan sentralisasi kewenangan pada pemerintah pusat yang sejatinya bertentangan dengan semangat otonomi daerah yang diatur dalam UUD 1945. ${ }^{13}$ Otonomi daerah merupakan bentuk riil dari demokrasi dimana hal tersebut merupakan pengimplementasian konsep areal division of power yang dipahami sebagai pembagian kekuasaan negara secara vertikal, yang memiliki implikasi adanya pembagian kewenangan penyelenggaraan pemerintahan antara Pemerintah Pusat dan Pemerintah Daerah. ${ }^{14}$ Menjadi sebuah pertanyaan mengenai pelaksanaan teori utilitarianism Jeremy Bentham tentang bagaimana kemanfaatan hukum yang menjadi salah satu tujuan dalam suatu pembentukan hukum dapat diberikan secara optimal kepada masyarakat, ketika sejatinya sentralisasi kewenangan penerbitan izin pertambangan kepada pemerintah pusat berpeluang untuk menyusutkan hubungan ekonomi politik antara pusat dan daerah.

Atas dasar pemikiran itulah, dalam penelitian hukum ini akan membahas mengenai dua permasalahan, yakni Pertama, mengenai politik hukum pengalihan kewenangan penerbitan izin pertambangan kepada pemerintah pusat dan Kedua, implikasi pengalihan kewenangan penerbitan izin pertambangan kepada pemerintah pusat terhadap kewenangan pemerintah daerah.

\section{B. METODE PENELITIAN}

Penelitian ini menggunakan metode yuridis normatif dengan menggunakan sumber kepustakaan sebagai bahan dasar untuk mengkaji permasalahan yang dibahas dalam penelitian ini. Pendekatan yang digunakan adalah pendekatan konseptual dan pendekatan undang-undang dengan melihat pada peraturan terkait seperti UUD 1945, UU Nomor 3 Tahun 2020, UU Nomor 4 Tahun 2009, UU Nomor 23 Tahun 2014 dan beberapa ketentuan lainnya. Data yang digunakan adalah data sekunder yang mencakup bahan hukum primer, sekunder dan tersier yang dikumpulkan melalui studi kepustakaan. Penelitian ini menggunakan teknis analisis kualitatif yang menganalisis data-data yang telah dikumpulkan untuk kemudian dituangkan dalam bentuk deskriptif.

\section{HASIL TEMUAN DAN PEMBAHASAN}

\section{Politik Hukum Pengalihan Penerbitan Izin Pertambangan Kepada Pemerintah Pusat}

Istilah politik hukum berasal dari bahasa Belanda rechtspolitiek yang terdiri atas 2 kata yakni rechts dan politiek. ${ }^{15}$ Rechts berarti hukum, sedangkan kata politik atau beleid dalam bahasa Indonesia memiliki arti kebijakan dimana oleh para ahli hukum hal tersebut

12 Arif Gunawan, Ini Revisi UU Minerba: Musuh Pemda, Kawan Pengusaha, https://www.cnbcindonesia.com/news/20200512113750-4-157843/ini-isi-revisi-uu-minerba-musuh-pemdakawan-pengusaha/2 diakses pada 13 Desember 2020.

${ }^{13}$ Indonesian Center for Enviromental Law, Beberapa Kritik Hukum Terhadap Perubahan UU No. 4 Tahun 2009 tentang Pertambangan Mineral dan Batubara, https://icel.or.id/wp-content/uploads/SeriAnalisis-ICEL-Minerba.rev1_-1.pdf diakses pada 13 Desember 2020, hlm. 10.

${ }^{14}$ Abdul Gafar Karim, 2003, Kompleksitas Persoalan Otonomi Daerah Di Indonesia, Yogyakarta : Pustaka Pelajar, hlm. 76.

${ }^{15}$ Imam Syaukani dan A. Ahsin Thohari, 1999, Dasar-Dasar Politik Hukum, Jakarta: PT. Raja Grafindo Persada, hlm. 19. 
ditafsirkan sebagai serangkaian kegiatan yang disarankan dalam lingkungan tertentu oleh seseorang, kelompok, maupun pemerintah dalam rangka mewujudkan suatu tujuan dengan memperlihatkan kesempatan dan tantangan terhadap pelaksana usulan kebijakan. ${ }^{16}$ Politik hukum dimaknai sebagai kegiatan yang menetapkan pola atau cara untuk membentuk hukum, mengawasi pelaksanaan hukum, dan melakukan pembaruan atas hukum demi tercapainya tujuan negara. ${ }^{17}$

Dalam konteks pertambangan minerba, politik hukum merupakan sebuah pedoman dalam pembentukkan kebijakan ataupun substansi yang berkenaan dengan pertambangan minerba serta bertindak sebagai sebuah sarana untuk menilai ataupun mengkritisi tiap-tiap produk hukum pertambangan yang telah dihasilkan guna melihat apakah hal tersebut sudah sejalan dengan tujuan negara. ${ }^{18}$ Pelaksanaan politik hukum harus didasarkan dengan nilai-nilai Pancasila dengan melandaskan pada empat hal dasar, yakni pertama, memperhatikan integrasi bangsa secara ideologis dan teritorial; kedua, terjaminnya keadilan sosial bagi masyarakat Indonesia; ketiga, tercerminnya pelaksanaan tata politik kenegaraan yang demokratis dan nomokratis; serta keempat, terciptanya toleransi dalam kehidupan masyarakatnya. ${ }^{19}$

Perubahan atas UU Nomor 4 Tahun 2009 melalui UU Nomor 3 Tahun 2020 yang diundangkan dalam Lembar Negara Tahun 2020 Nomor 147 Tambahan Lembaran Negara Nomor 6525 merupakan fase terbaru hukum pertambangan di Indonesia. Alasan diadakannya perubahan atas UU Nomor 4 Tahun 2009 dilandasi oleh beberapa hal, yakni: (i) sebagai tindak lanjut atas putusan Mahkamah Konstitusi yang mengabulkan baik sebagian maupun secara keseluruhan permohonan uji materil terhadap beberapa pasal dalam UU Minerba 2009; (ii) sinkronisasi kewenangan pemerintah pusat dan pemerintah daerah dalam urusan pemerintahan di bidang pertambangan minerba; (iii) adanya kasus tumpang-tindih perizinan pertambangan; (iv) sebagai upaya guna mengatasi ragam permasalahan di sektor pertambangan minerba seperti dalam bidang pengolahan dan pemurnian, data dan informasi pertambangan, pengawasan, perlindungan terhadap masyarakat terdampak, dan sanksi. ${ }^{20}$ Sektor pertambangan minerba memiliki peran sentral dalam upaya perwujudan kesejahteraan seluruh masyarakat secara berkeadilan sehingga adanya rekonstruksi hukum pertambangan minerba berorientasi pada tujuan yang bersifat ius constituendum agar kedepannya penyelenggaraan kegiatan pertambangan minerba dapat berjalan dengan efektif. ${ }^{21}$ Selain itu, UU yang disahkan pada masa pandemi COVID-19 tersebut juga dimaksudkan untuk meningkatkan pembangunan ekonomi negara. ${ }^{22}$

${ }^{16}$ Abdul Manan, 2018, Dinamika Politik Hukum di Indonesia, Jakarta : Kencana, hlm. 9.

${ }^{17}$ Hendra Karianga, 2013, Politik Hukum Dalam Pengelolaan Keuangan Daerah, Jakarta: Kencana, hlm. 23.

${ }^{18}$ Rachmad Safa'at, 2020, Rekonstruksi Politik Hukum Tata Kelola Pertambangan Mineral dan Batubara Berbasis Keadilan Sosial dan Keberlanjutan Lingkungan, Pidato Pengukuhan Profesor dalam Bidang Ilmu Hukum dan Sumber Daya Alam pada Fakultas Hukum Universitas Brawijaya, disampaikan pada Rapat Senat Terbuka Universitas Brawijaya Malang, 17 Desember 2020, hlm. 15.

${ }^{19}$ Abdul Manan, Op.Cit., hlm. 12.

${ }^{20}$ Dewan Perwakilan Rakyat Republik Indonesia, Op.Cit., hlm. 51-58.

${ }^{21}$ Ibid., hlm. 98.

22 Dewan Perwakilan Rakyat Republik Indonesia, RUU Minerba Fokus Pada Pertumbuhan Ekonomi,https://www.dpr.go.id/berita/detail/id/27695/t/RUU+Minerba+Fokus+Pada+Pertumbuhan+Ekon omi diakses 9 Januari 2021. 
Salah satu isu sentral dalam UU Nomor 3 Tahun 2020 adalah berkenaan dengan upaya pemerintah untuk melakukan pembenahan sistem perizinan pertambangan. Problematika perizinan pertambangan memang menjadi salah satu permasalahan yang masih menghantui kegiatan pertambangan minerba sampai saat ini. Setidaknya terdapat 2 persoalan mendasar yang mempengaruhi sulitnya mengatasi permasalahan di sektor perizinan, yakni adanya ego sektoral yang tetap bersikukuh untuk tidak tunduk pada upaya penyederhanaan perizinan dan cara pandang atas izin yang masih bersifat distortif sehingga izin tidak lagi dipandang sebagai salah satu instrumen hukum untuk mengendalikan kegiatan, melainkan sebagai sumber pendapatan. ${ }^{23}$

Realita problematika perizinan pertambangan dapat dilihat sejak diundangkannya UU Nomor 4 Tahun 2009 tentang Pertambangan Mineral dan Batubara dimana salah satu arah baru hukum pertambangan nasional masa itu adalah dengan melaksanaan desentralisasi dalam rangka pengelolaan pertambangan yang baik (good mining practies). ${ }^{24}$ Melalui UU tersebut, pemerintah kabupaten/kota memiliki kewenangan untuk menerbitkan izin pertambangan, namun dalam pelaksanaannya terdapat 6.415 izin pertambangan yang masih bermasalah alias non clean and clear $($ non- $\mathrm{CnC})$ dari total 10.566 izin pertambangan yang ada. ${ }^{25}$ Status izin pertambangan yang masih non- $\mathrm{CnC}$ menunjukkan kondisi dimana izin pertambangan belum memenuhi 2 aspek $C n C$, yakni telah terpenuhinya syarat administrasi yang sesuai dengan ketentuan peraturan perundang-undangan dan tidak adanya tumpang tindih kewilayahan. ${ }^{26} \mathrm{Hal}$ tersebut menjadi salah satu alasan diadakannya pengalihan kewenangan penerbitan izin pertambangan kepada pemerintah pusat dan pemerintah provinsi, selain permasalahan rendahnya kepastian hukum dan kepastian investasi bagi investor akibat pasang surut iklim investasi di Indonesia serta kondisi politik dan hukum yang tidak stabil yang diperparah dengan maraknya korupsi serta kondisi regulasi yang masih lemah ${ }^{27}$ melalui ketentuan Pasal 14 ayat (1) UU Nomor 23 Tahun 2014 tentang Pemerintahan Daerah yang mengatur mengenai urusan pemerintahan konkuren.

Harapan untuk mengentaskan problematika perizinan pertambangan melalui UU Nomor 23 Tahun 2014 pun masih belum mampu membawa perubahan secara signifikan. Selain menimbulkan pertentangan norma hukum yang mengatur mengenai kewenangan untuk menerbitkan izin pertambangan, nyatanya berdasarkan data Kementerian ESDM per 1 Januari 2019, masih terdapat 15,92 persen dari total 3.384 izin pertambangan minerba yang

${ }^{23}$ I Made Arya Utama, 2007, Hukum Lingkungan: Sistem Hukum Perizinan Berwawasan Lingkungan untuk Pembangunan Berkelanjutan, Bandung : Pustaka Sutra, hlm. 10.

${ }^{24}$ Gagasan yang tertuang dalam UU Minerba 2009 menunjukkan arah baru hukum pertambangan nasional yang mengakomodir prinsip kepentingan nasional (national interest), jaminan berusaha, pelaksanaan desentralisasi dalam rangka pengelolaan pertambangan yang baik (good mining practies), serta kemanfaatan untuk masyarakat. Lihat dalam Oheo Kaimuddin Haris, 2019, Tindak Pidana di Bidang Pertambangan, Surabaya: , Media Sahabat Cendikia, hlm. 31.

${ }^{25}$ Pusat Studi Hukum Energi dan Pertambangan, Evaluasi Penyimpangan Penerbitan Izin Usaha, http://pushep.or.id/wp-content/uploads/2020/03/Evaluasi-Penyimpangan-Penerbitan-Izin-UsahaPertambangan.pdf dikases 10 Januari 2021.

${ }^{26}$ Kementerian Energi dan Sumber Daya Mineral Republik Indonesia, Penataan IUP: Bukan Semata-mata untuk Mencabut Izin, https://www.esdm.go.id/id/media-center/arsip-berita/penataan-iupbukan-semata-mata-untuk-mencabut-izin diakses 10 Januari 2021.

${ }^{27}$ Rizkyana Zaffrinda Putri, 2015, Kajian Politik Hukum Tentang Perubahan Kewenangan Pemberian Izin Usaha Pertambangan Mineral dan Batubara di Indonesia Dari Undang-Undang Nomor 32 Tahun 2004 ke Undang-Undang Nomor 23 Tahun 2014 tentang Pemerintahan Daerah, Tesis: Fakultas Hukum Universitas Diponegoro Semarang, hlm. 100-107. 
masih berstatus non-CnC. ${ }^{28}$ Pengalihan kewenangan penerbitan izin tersebut juga menimbulkan permasalahan seperti lambatnya praktik pengelolaan minerba akibat ketidaksiapan baik dari pemerintah provinsi maupun pemerintah kabupaten/kota atas pengalihan kewenangan tersebut. Ketidaksiapan tersebut ditenggarai oleh problematika terbatasnya jumlah dan kualitas SDM hingga kurangnya pemahaman yang dimiliki oleh pemerintah provinsi dalam melaksanakan teknis pengelolaan minerba yang sudah dijalankan oleh pemerintah kabupaten/kota sebelumnya. Hal ini tentu berimplikasi pada lamanya proses perizinan dalam kegiatan pertambangan minerba. ${ }^{29}$

Kondisi tersebut menunjukkan masih belum terwujudnya sistem perizinan pertambangan yang terintegrasi dengan baik. Ombudsman Republik Indonesia bahkan menyebutkan tata kelola perizinan pertambangan Indonesia masih buruk yang dibuktikan dengan data bahwa sepanjang tahun 2019, terdapat 97 laporan terkait perlaksanaan kegiatan pertambangan minerba dimana laporan tersebut didominasi oleh problematika dalam tata kelola perizinan pertambangan. ${ }^{30} \mathrm{Hal}$ ini tentunya akan menimbulkan dampak yang merugikan pada berbagai aspek, seperti aspek hukum, pelayanan publik, kepentingan lingkungan hidup, hingga aspek ekonomi. Kebutuhan untuk melakukan pembenahan sistem perizinan dalam bidang pertambangan minerba menjadi hal yang sangat mendesak, mengingat pembangunan hukum saat ini menghendaki dibentuknya peraturan perundangundangan yang mampu memberikan jaminan kepastian hukum, efektif, terbuka, dan cenderung tidak berbelit-belit. ${ }^{31}$ Selain itu, aspek pembenahan sistem perizinan juga menjadi salah satu dari 7 agenda prioritas dalam tata kelola pertambangan yang didalamnya mencakup (i) pembenahan sistem perizinan dan tata guna lahan, (ii) tata kelola produksi perdagangan dan komunitas, (iii) pembenahan sistem pajak atau penerimaan negara dan aspek keuangan investasi, (iv) pengembangan wilayah dan efektivitas pelaksanaan desentralisasi, (v) pengawasan standar good mining practice (GMP) dan penanganan dampak sosial lingkungan, (vi) peningkatan nilai tambah dan pengembangan industri hilir, dan (vii) penegakkan hukum pemberantasan korupsi. ${ }^{32}$

Upaya pembenahan sistem perizinan pertambangan yang dilakukan oleh pemerintah dalam UU Nomor 3 Tahun 2020 diwujudkan dalam bentuk pengalihan penerbitan izin pertambangan kepada pemerintah pusat. Hal ini merupakan implikasi dari perubahan paradigma penguasaan pertambangan minerba dalam UU Nomor 3 Tahun 2020 yang tidak lagi melibatkan pemerintah daerah sehingga menghapus ketentuan Pasal 7 dan Pasal 8 UU Nomor 4 Tahun 2009 yang mengatur kewenangan pemerintah daerah dalam pengelolaan kegiatan pertambangan minerba. Pengalihan kewenangan tersebut menimbulkan reaksi keras dari kalangan masyarakat yang menilai bahwa hal tersebut bertentangan dengan nilai-nilai konstitusi dan semangat reformasi serta memperbesar

28 CNN Indonesia, ESDM Desak Gubernur Cabut Ratusan Izin Tambang Bermasalah, https://www.cnnindonesia.com/ekonomi/20190109155055-85-359627/esdm-desak-gubernur-cabut-ratusanizin-tambang-bermasalah diakses 10 Januari 2021.

${ }^{29}$ Dewan Perwakilan Rakyat Republik Indonesia, Op.Cit., h. 39.

30 Kautsar Widya Prabowo, Ombudsman: Tata Kelola Perizinan Pertambangan Buruk, https://www.medcom.id/nasional/peristiwa/9K5r1RRN-ombudsman-tata-kelola-perizinan-pertambanganburuk diakses 10 Januari 2021.

${ }^{31}$ I Made Arya Utama, Op.Cit., h. 8.

32 Mayang Sari, Tujuh Agenda Prioritas Tata Kelola Pertambangan di Indonesia, https://duniatambang.co.id/Berita/read/635/Tujuh-Agenda-Prioritas-Tata-Kelola-Pertambangan-diIndonesia diakses pada 12 Januari 2021. 
peluang terjadinya oligarki politik dan bisnis yang berkenaan dengan izin investasi ${ }^{33}$, sehingga dianggap hanya memihak pada kepentingan para pengusaha tambang. Penolakan atas hadirnya UU Nomor 3 Tahun 2020 dibuktikan dengan adanya uji materil yang dilakukan oleh sejumlah pihak dari berbagai lapisan masyarakat ke Mahkamah Konstitusi. ${ }^{34}$

Sejatinya, landasan yuridis politik hukum pengelolaan sumber daya alam, termasuk didalamnya adalah sektor pertambangan minerba terletak pada ketentuan Pasal 33 UUD 1945. Pasal 33 sendiri terdiri atas 5 ayat, dimana ayat (4) dan (5) hadir melalui amandemen keempat UUD 1945. Namun, menurut Kwik Kian Gie sebagaimana yang dikutip oleh Indah Dwi Qurbani, amandemen yang dilakukan terhadap Pasal 33 tersebut menimbulkan nuansa liberalisasi dalam pengelolaan sumber daya alam. ${ }^{35}$ Tidak hanya itu, hal tersebut menimbulkan pertentangan antar ayat dalam Pasal 33, ketentuan ayat (1), (2), dan (3) cenderung bernuansa ekonomi kerakyatan, sedangkan ayat (4) dan (5) cenderung berkarakter neo-liberalisme yang membiaskan arah dan tujuan yang hendak diwujudkan dalam pelaksanaan pengelolaan sumber daya alam. Hal ini yang kemudian berimplikasi pada hadirnya aturan hukum yang menihilkan nilai keadilan dan keberlanjutan lingkungan. Aturan hukum yang cenderung mengabaikan nilai keadilan dan keberlanjutan lingkungan tersebut identik dengan tata kelola pertambangan yang hanya mengedepankan keuntungan ekonomi semata. ${ }^{36}$

Perdebatan dalam menafsirkan Pasal 33 UUD memang menjadi suatu hal yang tidak dapat dihindari. Namun perlu diingat bahwa UUD 1945 memang merupakan sebuah aturan hukum yang bersifat sebagai hukum dasar sehingga hanya memuat norma hukum secara garis besar ataupun prinsip saja. ${ }^{37}$ Penafsiran atas norma dalam UUD 1945 yang diterjemahkan dalam bentuk UU sesuai dengan arah politik hukum yang dimaksudkan oleh para pembentuk undang-undang sudah sepatutnya sejalan dengan ketentuan yang termuat dalam konstitusi dan cita-cita masyarakat.

Pembentukan hukum yang hanya didasari pada ambisi pembentuk undang-undang hanya akan membuat hukum tidak berjalan secara maksimal, ${ }^{38}$ seperti era hukum pertambangan pada masa orde baru yang diatur dalam UU Nomor 11 Tahun 1967 tentang Ketentuan-Ketentuan Pokok Pertambangan yang kental akan nuansa sentralistiknya. Aturan hukum tersebut justru menunjukkan beberapa kelemahan substansial seperti Pertama, hukum hanya digunakan sebagai sebuah legal instrument untuk mencapai target pertumbuhan ekonomi sehingga kegiatan pengelolaan sumber daya alam berorientasi pada eksploitasi dan cenderung mengabaikan kepentingan konservasi serta keberlanjutan sumber daya alam; Kedua, mengabaikan ragam akses dan kepentingan serta mematikan potensi

${ }_{33}$ Haris Prabowo, Greenpeace: UU Minerba Cederai Desentralisasi Daerah Era Rerformasi, https://tirto.id/greenpeace-uu-minerba-cederai-desentralisasi-daerah-era-reformasi-fMe6 diakses 12 Januari 2020.

${ }^{34}$ Ridwan Nanda Mulyana, Ini Pihak-Pihak Yang Menggugat UU Minerba Ke Mahkamah Konstitusi, $\quad$ https://industri.kontan.co.id/news/ini-pihak-pihak-yang-menggugat-uu-minerba-kemahkamah-konstitusi diakses 13 Januari 2021.

${ }^{35}$ Indah Dwi Qurbani, 2012, Politik Hukum Pengelolaan Minyak dan Gas Bumi di Indonesia, Arena Hukum, Vol. 6 No. 2hlm. 119.

${ }^{36}$ Rachmad Safaat, Op.Cit, hlm. 8-9.

${ }^{37}$ Taufiqurrohman Syahuri dan Muhammad Helmi Fahrozi, 2020, Konstitusionalitas Pasal 222 UU Nomor 7 Tahun 2017 tentang Pemilu (Presidential Treshold), Al Wasath Jurnal Ilmu Hukum, Vol. 1 No. 1, hlm. 30.

${ }^{38}$ Ibid., hlm 31. 
ekonomi masyarakat karena cenderung berpihak pada pemodal besar (capital oriented); Ketiga paradigma pengelolaan yang sentralistik karena menganut paham penguasaan negara hanya dilaksanakan oleh negara/pemerintah (state-based resource management); Keempat tidak terintegrasinya sistem ekologi akibat pendekatan yang bernuansa sektoral; Kelima nihilnya koordinasi dan keterpaduan antar pemerintahan dalam pengelolaan sumber daya alam; Keenam terjadi pengabaian atas hak-hak asasi manusia, khususnya pada hak masyarakat adat dalam kemajemukan hukum penguasaan dan pemanfaatan sumber daya alam. ${ }^{39}$

Selain itu, pengalihan kewenangan penerbitan izin pertambangan kepada pemerintah pusat dapat dikatakan tidak sesuai dengan prinsip-prinsip pengelolaan sumber daya alam yang termaktub dalam Pasal 4 TAP MPR Nomor IX/MPR/2001 tentang Pembaruan Agraria dan Pengelolaan Sumber Daya Alam yang meliputi: “(a) memelihara dan mempertahankan keutuhan Negara Kesatuan Republik Indonesia; (b) menghormati dan menjunjung tinggi hak asasi manusia; (c) menghormati supremasi hukum dengan mengakomodasi keanekaragaman dalam unifikasi hukum; (d) mensejahterakan rakyat, terutama melalui peningkatan kualitas sumber daya manusia Indonesia; (e) mengembangkan demokrasi, kepatuhan hukum, transparansi, dan optimalisasi partisipasi rakyat; ( $f$ ) mewujudkan keadilan termasuk kesetaraan gender dalam penguasaan, pemilikan, penggunaan, pemanfaatan, dan pemeliharaan sumber daya agraria/sumber daya alam; $(g)$ memelihara keberlanjutan yang dapat memberi manfaat yang optimal, baik untuk generasi sekarang maupun generasi mendatang, dengan tetap memperhatikan daya tampung dan daya dukung lingkungan; (h) melaksanakan fungsi sosial, kelestarian, dan fungsi ekologis sesuai dengan kondisi sosial budaya setempat; (i) meningkatkan keterpaduan dan koordinasi antar sektor pembangunan dan antar daerah dalam pelaksanaan pembaharuan agraria dan pengelolaan sumber daya alam; ( $j$ ) mengakui, menghormati, dan melindungi hak masyarakat hukum adat dan keragaman budaya bangsa atas sumber daya agraria/sumber daya alam; ( $k$ ) mengupayakan keseimbangan hak dan kewajiban negara, pemerintah (pusat, daerah provinsi, kabupaten/kota, dan desa atau yang setingkat), masyarakat dan individu; serta (l) melaksanakan desentralisasi berupa pembagian kewenangan di tingkat nasional, daerah provinsi, kabupaten/kota, dan desa atau yang setingkat, berkaitan dengan alokasi dan pengelolaan sumber daya agraria/sumber daya alam." Jika dicermati, prinsip-prinsip pengelolaan sumber daya alam yang termaktub dalam TAP MPR Nomor IX/MPR/2001 memiliki nafas yang sama dengan prinsip-prinsip global pengelolaan sumber daya alam yang mencakup prinsip keadilan, demokrasi, dan keberlanjutan lingkungan. Artinya, sudah sepatutnya prinsip-prinsip pengelolaan sumber daya alam dijadikan pula sebagai sebuah landasan politik hukum sumber daya alam dalam membentuk tiap-tiap kebijakan baik yang bersifat regeling maupun bechsikking ${ }^{40}$ termasuk di dalamnya sektor pertambangan minerba. Pengabaian terhadap prinsip-prinsip pengelolaan sumber daya negara sejatinya hanya menimbulkan ketidakselarasan dalam pembentukan kebijakan hukum pertambangan yang berimplikasi pada tidak tercapainya tujuan untuk sebesar-besarnya kemakmuran rakyat.

${ }^{39}$ I Nyoman Nurjaya, Prinsip-Prinsip Global Pengelolaan Sumber Daya Alam: Implikasinya Bagi Politik Pembangunan Hukum Nasional, dilansir melalui laman https://simposiumjai.ui.ac.id/wpcontent/uploads/20/2020/03/8.2.1-I-Nyoman-Nurjaya.pdf, h. 4-5.

${ }^{40}$ Herdiansyah Hamzah, 2019, Politik Hukum Sumber Daya Alam, Jurnal Jurisprudentie, Vol. 6 No. 2, hlm. 288 . 


\section{Implikasi Pengalihan Kewenangan Penerbitan Izin Pertambangan Kepada Pemerintah Pusat Terhadap Kewenangan Pemerintah Daerah}

Hadirnya UU Nomor 3 Tahun 2020 membawa babak baru dalam mengatur kewenangan yang dimiliki oleh pemerintah di sektor pertambangan minerba. Sebagaimana yang telah disebutkan sebelumnya bahwa UU Nomor 3 Tahun 2020 menunjukkan pergeseran paradigma pelaksana penguasaan negara atas pertambangan minerba dengan memusatkan seluruh kewenangan kepada pemerintah pusat, termasuk di dalamnya kewenangan untuk menerbitkan izin pertambangan yang membawa implikasi terhadap kewenangan pemerintah daerah.

Penerbitan izin pertambangan merupakan kewenangan yang dimiliki oleh pemerintah kepada pemegang izin untuk mengelola kegiatan usaha pertambangan dalam rangka mencapai tujuan konkret sekalipun menyimpangi ketentuan-ketentuan yang dilarang. ${ }^{41}$ Secara filosofis, penerbitan izin pertambangan ditujukan untuk meningkatkan perekonomian negara dan mencapai kesejahteraan dan kemakmuran masyarakat. ${ }^{42}$ Penerbitan izin atas suatu kegiatan usaha termasuk dalam usaha pertambangan minerba berfungsi sebagai sarana untuk melakukan kontrol yang menggambarkan hubungan hukum yang ada antara negara dengan badan hukum atau individu. ${ }^{43}$ Artinya dapat dikatakan bahwa esensi izin pertambangan adalah bertindak sebagai salah satu instrument pencegahan hukum (legal prevention) dalam mengendalikan kegiatan usaha pertambangan minerba.

Perubahan besar dalam UU Nomor 3 Tahun 2020 terkait penerbitan izin ditunjukkan melalui ketentuan Pasal 4 ayat (2) Jo. Pasal 35 ayat (1) yang menyebutkan bahwa "Usaha Pertambangan dilaksanakan berdasarkan Perizinan Berusaha dari Pemerintah Pusat." UU Minerba terbaru ini juga sekaligus menghapuskan ketentuan dalam Matriks Pembagian Urusan Pemerintahan Konkuren yang membagi urusan pemerintahan dalam bidang energi dan sumber daya mineral termasuk didalamnya urusan pemerintahan di sektor pertambangan minerba sebagaimana yang dimaksud dalam Lampiran UU Nomor 23 Tahun $2014{ }^{44}$ sehingga terjadi sinkronisasi antar norma hukum yang mengatur mengenai kewenangan di bidang pertambangan minerba. Sebagaimana yang telah dijelaskan sebelumnya, bahwa sebelum terbitnya UU Nomor 3 Tahun 2020, terjadi pertentangan norma antara UU Nomor 4 Tahun 2009 dengan UU Nomor 23 Tahun 2014 terkait kewenangan yang dimiliki oleh pemerintah pusat, pemerintah provinsi, dan pemerintah kabupaten/kota dalam sektor pertambangan minerba, termasuk dalam hal penerbitan izin. Artinya melalui UU Nomor 3 Tahun 2020, pemerintah daerah baik pemerintah provinsi maupun pemerintah kabupaten/kota tidak lagi memiliki kewenangan atributif untuk menerbitkan izin pertambangan. Kondisi ini juga dapat dikatakan sebagai resentralisasi penerbitan izin

${ }^{41}$ Oheo K. Haris, 2015, Good Governance (Tata Kelola Pemerintahan Yang Baik) Dalam Pemberian Izin Oleh Pemerintah Daerah di Bidang Pertambangan, Jurnal Yuridika, Vol. 30 No. 1, hlm. 66.

${ }^{42}$ Ibid., hlm. 59.

${ }^{43}$ Kartono, 2017, Analisa Konflik Hukum Wewenang Pengawasan Kegiatan Pertambangan Pasca Berlakunya Undang-Undang Pemerintahan Daerah Tahun 2014, Jurnal Bina Hukum Lingkungan, Vol. 2 No. 1, hlm. 33.

${ }^{44}$ Pasal 173B Undang-Undang Nomor 3 Tahun 2020 tentang Perubahan Atas Undang-Undang Nomor 4 Tahun 2009 tentang Pertambangan Mineral dan Batubara. 
pertambangan setelah pada masa sebelumnya nuansa penerbitan izin pertambangan dilandasi pada semangat desentralisasi dan otonomi daerah.

Namun, terdapat satu hal yang menarik terkait kewenangan penerbitan izin pertambangan ini, dimana ketentuan Pasal 35 ayat (4) UU Nomor 3 Tahun 2020 yang menyebutkan bahwa "Pemerintah Pusat dapat mendelegasikan kewenangan pemberian Perizinan Berusaha sebagaimana dimaksud pada ayat (2) kepada Pemerintah Daerah provinsi sesuai dengan ketentuan peraturan perundang-undangan." Ketentuan pasal ini menyiratkan adanya peluang untuk melibatkan pemerintah daerah provinsi untuk terlibat dalam urusan penerbitan izin pertambangan. Menjadi sebuah pembahasan yang menarik ketika ketentuan pasal tersebut secara langsung menggunakan frasa delegasi dimana secara umum ketentuan dalam undang-undang biasanya menggunakan frasa diserahkan ataupun lain sebagainya. ${ }^{45}$

Sebagaimana yang diketahui bahwa delegasi menurut H.D van Wijk/Willem Koninenbelt sebagaimana yang dikutip oleh Ridwan HR merupakan pelimpahan wewenang pemerintahan dari satu organ pemerintahan kepada organ pemerintahan lainnya. Hal ini menunjukkan bahwa kewenangan delegasi tidak diberikan dalam konteks hubungan antara atasan-bawahan (hierarki) yang membedakannya dengan kewenangan mandat. Karakteristik khas dari kewenangan yang diperoleh secara delegasi adalah bahwa tanggung jawab dan tanggung gugat yang dimiliki oleh delegans beralih kepada delegataris sehingga delegans tidak dapat menggunakan kewenangan itu lagi kecuali ada pencabutan dengan berpegang pada asas contarius actus. ${ }^{46}$

Jika melihat kedalam Penjelasan UU Nomor 3 Tahun 2020 khususnya penjelasan Pasal 35 ayat (4), dapat terlihat bahwa maksud dari ketentuan pasal tersebut adalah pendelegasian kewenangan perizinan berusaha yang dilakukan oleh pemerintah pusat kepada pemerintah daerah dilakukan dalam konteks pemberian Izin Pertambangan Rakyat (IPR) dan SIPB (Surat Izin Penambangan Batuan) yang dilaksanakan berdasarkan prinsip efektivitas, efisiensi, akuntabilitas, dan eksternalitas. Artinya, dengan melihat karakteristik dari kewenangan delegasi yang telah disebutkan diatas, masih ada kewenangan yang dimiliki oleh pemerintah daerah provinsi dalam menerbitkan izin pertambangan walaupun bentuk izinnya terbatas.

Keterbatasan kewenangan yang dimiliki oleh pemerintah daerah dalam penerbitan izin pertambangan ini merupakan salah satu konsekuensi dari konsep negara kesatuan yang dianut oleh Indonesia, dimana otoritas kewenangan berada pada pemerintah pusat. ${ }^{47}$ Sekalipun konstitusi telah mengamanatkan untuk diadakannya pelaksanaan otonomi daerah dalam melaksanakan urusan pemerintah, namun jika melihat ketentuan Pasal 18 ayat (5) UUD 1945 yang menyebutkan bahwa "Pemerintahan daerah menjalankan otonomi seluasseluasnya, kecuali urusan pemerintahan yang oleh undang-undang ditentukan sebagai urusan Pemerintah Pusat". Hal ini menunjukkan bahwa kewenangan yang dimiliki oleh pemerintah daerah dapat diberikan dan kemudian diambil alih kembali sesuai dengan kebijakan yang telah ditetapkan oleh para pembentuk undang-undang. Pada praktiknya, dalam konteks

\footnotetext{
${ }^{45}$ Pusat Studi Hukum Energi dan Pertambangan, Pembagian Kewenangan Pusat dan Daerah Sektor Pertambangan Minerba dalam Perspektif Hukum Administrasi Negara, https://pushep.or.id/pembagian-kewenangan-pusat-dan-daerah-sektor-pertambangan-minerba-dalamperspektif-hukum-administrasi-negara/ diakses 15 Januari 2021.

${ }^{46}$ Ridwan HR, 2016, Hukum Administrasi Negara Edisi Revisi, Jakarta: Rajawali Pers, hlm. 104-107.

${ }^{47}$ Nabilla Desyalika Putri dan Dian Agung Wicaksono, Op.Cit., hlm. 27.
} 
hubungan antara pemerintah pusat dengan pemerintah daerah selalu ditemukan konflik tarik menarik kepentingan serta upaya yang dilakukan oleh pemerintah pusat untuk memegang kekuasaan atas seluruh urusan pemerintahan. ${ }^{48}$

Konsekuensi dari terbitnya suatu izin pertambangan tentunya tidak terlepas dari pengawasan yang dilakukan atas kegiatan pertambangan minerba. Pengawasan ini sendiri merupakan salah satu bentuk perhatian khusus terhadap kegiatan-kegiatan yang memiliki potensi terjadinya bahaya, kerugian, gangguan bagi lingkungan, dan pihak ketiga lainnya. Tentu sudah menjadi sebuah rahasia umum bahwa kegiatan pertambangan minerba merupakan salah satu kegiatan sumber daya alam yang memiliki sifat destruktif tinggi sehingga dapat menimbulkan kerugian bagi lingkungan hidup dan masyarakat yang ada di wilayah pertambangan. ${ }^{49}$

Jika melihat dalam ketentuan Pasal 140 UU Nomor 3 Tahun 2020, kewenangan untuk melakukan pengawasan atas kegiatan pertambangan yang memiliki IPR dan SIPB memang dilakukan oleh Menteri sebagai bagian dari pemerintah pusat. Namun, apabila kedepannya terjadi pendelegasian wewenang penerbitan izin pertambangan dalam bentuk IPR dan SIPB yang dilandasi pada ketentuan Pasal 35 ayat (4) UU Nomor 3 Tahun 2020, artinya kewenangan untuk melakukan pengawasan tersebut akan beralih kepada pemerintah daerah provinsi. Tentunya pemerintah daerah tidak lagi memiliki wewenang untuk melakukan pengawasan terhadap bentuk izin pertambangan lain sebagaimana yang dimaksud dalam Pasal 35 ayat (3) UU Nomor 3 Tahun 2020 mengingat kewenangan yang dimilikinya saat ini sangat terbatas.

Melihat keterbatasan ruang gerak yang dimiliki oleh pemerintah daerah dalam UU Nomor 3 Tahun 2020 tentu menimbulkan pertanyaan mengenai bagaimana kemanfaatan hukum atas perubahan hukum tersebut. Kemanfaatan sendiri menjadi salah satu asas hukum pertambangan minerba sebagaimana yang termaktub dalam ketentuan Pasal 2 UU Nomor 4 Tahun 2009. Makna dari asas manfaat ini memiliki kesesuaian konsep dengan kemanfaatan hukum yang dikemukakan oleh Jeremy Bentham yang memiliki pandangan bahwa hukum harus memberikan manfaat atau memiliki sifat kegunaan untuk orang banyak (to serve utility). ${ }^{50}$

Di satu sisi memang pengalihan kewenangan penerbitan izin ini dilaksanakan untuk mewujudkan suatu sistem perizinan pertambangan yang efisien, namun tidak dapat dipungkiri bahwa akibat dari jangkauan wilayah pertambangan yang luas serta minimnya kewenangan yang dimiliki oleh pemerintah daerah sebagai pihak 'tuan rumah' untuk melakukan pengawasan kegiatan pertambangan minerba, bukan tidak mungkin hal tersebut justru akan berdampak pada tidak intensifnya proses pemantauan, pembinaan, dan pengawasan atas kegiatan pertambangan minerba. Minimnya peran pemerintah daerah dalam kegiatan pertambangan minerba dapat menimbulkan sejumlah permasalahan, sebab pada dasarnya hubungan diantara pemerintah pusat dengan pemerintah daerah yang dikonstruksikan dalam otonomi daerah bertujuan untuk mendekatkan proses pengambilan keputusan dalam pembentukan kebijakan publik sehingga hal tersebut mampu

48 Ibid., dikutip dari Ni'matul Huda, 2012, Hukum Pemerintahan Daerah, Bandung : Nusamedia, hlm.

1.

${ }^{49}$ Ibid.

${ }^{50}$ Oheo Kaimuddin Haris, Op.Cit., hlm. 32-33. 
mewujudkan kesejahteraan dan keadilan di tengah masyarakat ${ }^{51}$ serta tercapainya efektivitas dan efisiensi dalam rangka memberikan pelayanan. ${ }^{52}$ Seharusnya hukum pertambangan yang ada saat ini bergerak untuk menciptakan sinergisitas antar pemerintahan bukan dengan menempatkan pemerintah pusat dan pemerintah daerah pada jalan yang berbeda ${ }^{53}$ demi keberlangsungan pembangunan di masa depan.

\section{KESIMPULAN}

Politik hukum pertambangan dipandang tidak hanya berperan sebagai pedoman dalam membentuk kebijakan dalam hukum pertambangan, melainkan juga digunakan untuk mengkritisi tiap-tiap kebijakan yang ada untuk melihat apakah hal tersebut sesuai dengan tujuan negara. Melihat adanya pengalihan penerbitan izin pertambangan kepada pemerintah pusat dapat dilihat bahwa hal tersebut bertujuan untuk mengurai permasalahan perizinan yang nantinya akan mempermudah iklim berinvestasi di Indonesia sehingga dapat meningkatkan pertumbuhan ekonomi Indonesia, namun apabila dilihat melalui kacamata Pasal 33 UUD 1945 dan TAP MPR Nomor IX/MPR/2001 yang menjadi landasan politik hukum pengelolaan kegiatan pertambangan minerba, terdapat ketidaksesuaian antara aturan tersebut dengan nilai konstitusi, keadilan, keberlanjutan lingkungan, hingga semangat reformasi. Selain itu, pengalihan kewenangan penerbitan izin tersebut juga berdampak pada kewenangan yang dimiliki oleh pemerintah daerah dimana saat ini pemerintah daerah tidak memiliki kewenangan atributif dalam hal penerbitan izin pertambangan. Masih terdapat peluang untuk menerbitkan izin pertambangan, namun hal tersebut terbatas dalam bentuk IPR dan SIPB yang nantinya akan berimplikasi pada terbatasnya wewenang pengawasan, dengan catatan bahwa pemerintah pusat telah mendelegasikan kewenangan tersebut berdasarkan ketentuan Pasal 35 ayat (4) UU Nomor 3 Tahun 2020. Seharusnya pembentuk undang-undang lebih memperhatikan nilai kemanfaatan yang menjadi salah satu asas pertambangan minerba dalam membentuk aturan hukum di bidang pertambangan demi terwujudnya kesejahteraan dan kemakmuran rakyat serta menjaga keberlangsungan pertambangan di masa depan.

\section{REFERENSI}

\section{Buku}

Haris, Oheo Kaimuddin. (2019). Tindak Pidana di Bidang Pertambangan, Surabaya: Media Sahabat Cendikia.

HR, Ridwan. (2016). Hukum Administrasi Negara Edisi Revisi. Jakarta: Rajawali Pers. HS, Salim. (2012). Hukum Pertambangan Indonesia. Jakarta: Rajawali Pers.

${ }^{51}$ Siswanto Sunarno, 2006, Hukum Pemerintahan Daerah di Indonesia, Jakarta : Sinar Grafika, hlm. 249-250.

${ }^{52}$ HAW Widjaja, 2009, Otonomi Daerah dan Daerah Otonom, Jakarta : PT Raja Grafindo Persada, hlm. 22.

${ }^{53}$ Pusat Studi Hukum Energi dan Pertambangan, Sentralisasi Sektor Pertambangan Jadikan Daerah Tidak Merasa Memiliki dan Peduli Terhadap Dampak Lingkungan, https://pushep.or.id/sentralisasi-sektorpertambangan-jadikan-daerah-tidak-merasa-memiliki-dan-peduli-terhadap-dampak-lingkungan/ diakses 17 Januari 2021. 
Karianga, Hendra. (2013). Politik Hukum Dalam Pengelolaan Keuangan Daerah. Jakarta: Kencana.

Karim, Abdul Gafar. (2003). Kompleksitas Persoalan Otonomi Daerah Di Indonesia. Yogyakarta : Pustaka Pelajar.

Manan, Abdul. (2018). Dinamika Politik Hukum di Indonesia. Jakarta : Kencana.

Sunarno, Siswanto. (2006). Hukum Pemerintahan Daerah di Indonesia. Jakarta : Sinar Grafika.

Syaukani, Imam., dan A. Ahsin Thohari. (1999). Dasar-Dasar Politik Hukum. Jakarta: PT. Raja Grafindo Persada.

Utama, I Made Arya Utama. (2007). Hukum Lingkungan: Sistem Hukum Perizinan Berwawasan Lingkungan untuk Pembangunan Berkelanjutan. Bandung : Pustaka Sutra.

Widjaja, HAW. (2009). Otonomi Daerah dan Daerah Otonom. Jakarta : PT Raja Grafindo Persada.

\section{Artikel Jurnal}

Hamzah, Herdiansyah. (2019). Politik Hukum Sumber Daya Alam. Jurnal Jurisprudentie. 6(2).

Harris, Oheo K. (2015). Good Governance (Tata Kelola Pemerintahan Yang Baik) Dalam Pemberian Izin Oleh Pemerintah Daerah di Bidang Pertambangan. Jurnal Yuridika. 30(1).

Isnaeni, Diyan. (2018). Implikasi Yuridis Kewenangan Pemerintah Daerah Dalam Pemberian Ijin Usaha Pertambangan Menurut Undang-Undang Nomor 23 Tahun 2014. Jurnal Yurispruden. 1(1).

Kartono. (2017). Analisa Konflik Hukum Wewenang Pengawasan Kegiatan Pertambangan Pasca Berlakunya Undang-Undang Pemerintahan Daerah Tahun 2014. Jurnal Bina Hukum Lingkungan. 2(1).

Nalle, Victor Imanuel Wiliamson. (2012). Hak Menguasai Negara Atas Mineral dan Batubara Pasca Berlakunya Undang-Undang Minerba. Jurnal Konstitusi. 9(3).

Putri, Nabilla Desyalika., dan Dian Agung Wicaksono. (2016). Implikasi Legislasi Pengambilalihan Kewenangan di Bidang Pertambangan Mineral dan Batubara Oleh Pemerintah Pusat (Legislation Implication Of The Takeover Authority In Mineraland Coal Mining By The Central Government). Jurnal Legislasi. 3(1).

Putri, Rizkyana Zaffrinda., Lita Tyesta A.L.W. (2015). Kajian Politik Hukum Tentang Perubahan Kewenangan Pemberian Izin Usaha Pertambangan Mineral dan Batubara. Jurnal Law Reform. 11(2)

Qurbani, Indah Dwi. (2012). Politik Hukum Pengelolaan Minyak dan Gas Bumi di Indonesia. Arena Hukum. 6(2). 
Syahuri, Taufiqurrohman., dan Muhammad Helmi Fahrozi. (2020). Konstitusionalitas Pasal 222 UU Nomor 7 Tahun 2017 tentang Pemilu (Presidential Treshold), Al Wasath Jurnal Ilmu Hukum. 1(1).

\section{Internet}

CNN Indonesia, ESDM Desak Gubernur Cabut Ratusan Izin Tambang Bermasalah, https://www.cnnindonesia.com/ekonomi/20190109155055-85-359627/esdmdesak-gubernur-cabut-ratusan-izin-tambang-bermasalah diakses 10 Januari 2021.

Dewan Perwakilan Rakyat Republik Indonesia, RUU Minerba Fokus Pada Pertumbuhan Ekonomi, https://www.dpr.go.id/berita/detail/id/27695/t/RUU+Minerba+Fokus+Pada+Pert umbuhan+Ekonomi diakses 9 Januari 2021.

Gunawan, Arif., Ini Revisi UU Minerba: Musuh Pemda, Kawan Pengusaha, https://www.cnbcindonesia.com/news/20200512113750-4-157843/ini-isi-revisiuu-minerba-musuh-pemda-kawan-pengusaha/2 diakses pada 13 Desember 2020.

Indonesian Center for Enviromental Law, Beberapa Kritik Hukum Terhadap Perubahan UU No. 4 Tahun 2009 tentang Pertambangan Mineral dan Batubara, https://icel.or.id/wp-content/uploads/Seri-Analisis-ICEL-Minerba.rev1_-1.pdf diakses pada 13 Desember 2020.

Kementerian Energi dan Sumber Daya Mineral Republik Indonesia, Penataan IUP: Bukan Semata-mata untuk Mencabut Izin, https://www.esdm.go.id/id/mediacenter/arsip-berita/penataan-iup-bukan-semata-mata-untuk-mencabut-izin diakses 10 Januari 2021.

Mulyana, Ridwan Nanda., Ini Pihak-Pihak Yang Menggugat UU Minerba Ke Mahkamah Konstitusi, https://industri.kontan.co.id/news/ini-pihak-pihak-yangmenggugat-uu-minerba-ke-mahkamah-konstitusi diakses 13 Januari 2021.

Petriella, Yanita., Adu Cepat antara RUU Cipta Kerja dan RUU Minerba, Ini Kata Ahli Tambang, https://ekonomi.bisnis.com/read/20200225/44/1205770/adu-cepatantara-ruu-cipta-kerja-dan-ruu-minerba-ini-kata-ahli-tambang diakses pada 13 Desember 2020.

Prabowo, Haris., Greenpeace: UU Minerba Cederai Desentralisasi Daerah Era Rerformasi, https://tirto.id/greenpeace-uu-minerba-cederai-desentralisasidaerah-era-reformasi-fMe6 diakses 12 Januari 2020.

Prabowo, Kautsar Widya., Ombudsman: Tata Kelola Perizinan Pertambangan Buruk, https://www.medcom.id/nasional/peristiwa/9K5r1RRN-ombudsman-tatakelola-perizinan-pertambangan-buruk diakses 10 Januari 2021.

Pusat Studi Hukum Energi dan Pertambangan, Evaluasi Penyimpangan Penerbitan Izin Usaha, http://pushep.or.id/wp-content/uploads/2020/03/Evaluasi- 
Penyimpangan-Penerbitan-Izin-Usaha-Pertambangan.pdf dikases 10 Januari 2021.

Pusat Studi Hukum Energi dan Pertambangan, Pembagian Kewenangan Pusat dan Daerah Sektor Pertambangan Minerba dalam Perspektif Hukum Administrasi Negara, https://pushep.or.id/pembagian-kewenangan-pusat-dan-daerah-sektorpertambangan-minerba-dalam-perspektif-hukum-administrasi-negara/ diakses 15 Januari 2021.

Pusat Studi Hukum Energi dan Pertambangan, Sentralisasi Sektor Pertambangan Jadikan Daerah Tidak Merasa Memiliki dan Peduli Terhadap Dampak Lingkungan, https://pushep.or.id/sentralisasi-sektor-pertambangan-jadikandaerah-tidak-merasa-memiliki-dan-peduli-terhadap-dampak-lingkungan/ diakses 17 Januari 2021.

Sari, Mayang., Tujuh Agenda Prioritas Tata Kelola Pertambangan di Indonesia, https://duniatambang.co.id/Berita/read/635/Tujuh-Agenda-Prioritas-TataKelola-Pertambangan-di-Indonesia diakses pada 12 Januari 2021.

\section{Lainnya}

Dewan Perwakilan Rakyat Republik Indonesia, 2018, Naskah Akademik Rancangan Undang-Undang tentang Perubahan Atas Undang-Undang Nomor 4 Tahun 2009 tentang Pertambangan Mineral dan Batu Bara, DPR RI: Jakarta.

Nurjaya, I Nyoman, Prinsip-Prinsip Global Pengelolaan Sumber Daya Alam: Implikasinya Bagi Politik Pembangunan Hukum Nasional, dilansir melalui laman https://simposiumjai.ui.ac.id/wp-content/uploads/20/2020/03/8.2.1-INyoman-Nurjaya.pdf.

Putri, Rizkyana Zaffrinda, (2015), Kajian Politik Hukum Tentang Perubahan Kewenangan Pemberian Izin Usaha Pertambangan Mineral dan Batubara di Indonesia Dari UndangUndang Nomor 32 Tahun 2004 ke Undang-Undang Nomor 23 Tahun 2014 tentang Pemerintahan Daerah, Tesis: Fakultas Hukum Universitas Diponegoro Semarang.

Putusan Mahkamah Konstitusi Nomor 002/PUU-I/2003 perihal Pengujian UndangUndang Nomor 22 Tahun 2001 tentang Minyak dan Gas Bumi terhadap UndangUndang Dasar Negara Republik Indonesia Tahun 1945, 15 Desember 2004.

Putusan Mahkamah Konstitusi Nomor 10/PUU-X/2012 perihal Pengujian UndangUndang Nomor 4 Tahun 2009 tentang Pertambangan Mineral dan Batubara terhadap Undang-Undang Dasar Negara Republik Indonesia Tahun 1945, 20 November 2012.

Safa'at, Rachmad, (2020), Rekonstruksi Politik Hukum Tata Kelola Pertambangan Mineral dan Batubara Berbasis Keadilan Sosial dan Keberlanjutan Lingkungan, Pidato Pengukuhan Profesor dalam Bidang Ilmu Hukum dan Sumber Daya Alam pada Fakultas Hukum Universitas Brawijaya, disampaikan pada Rapat Senat Terbuka Universitas Brawijaya Malang, 17 Desember 2020. 